\title{
Hepatozoon silvestris sp. nov.: morphological and molecular characterization of a new species of Hepatozoon (Adeleorina: Hepatozoidae) from the European wild cat (Felis silvestris silvestris)
}

\author{
ADNAN HODŽIĆ ${ }^{1}$, AMER ALIĆ ${ }^{2}$, SENAD PRAŠOVIĆ ${ }^{2}$, DOMENICO OTRANTO ${ }^{3}$, \\ GAD BANETH ${ }^{4}$ and GEORG GERHARD DUSCHER ${ }^{1 *}$ \\ ${ }^{1}$ Department of Pathobiology, Institute of Parasitology, University of Veterinary Medicine Vienna, Veterinaerplatz 1, \\ 1210 Vienna, Austria \\ ${ }^{2}$ Department of Pathology, Faculty of Veterinary Medicine, University of Sarajevo, Zmaja od Bosne 90, 71000 Sarajevo, \\ Bosnia and Herzegovina \\ ${ }^{3}$ Department of Veterinary Medicine, University of Bari, Str. prov. per Casamassima km 3, 70010 Valenzano, Italy \\ ${ }^{4}$ Koret School of Veterinary Medicine, Hebrew University of Ferusalem, P.O. Box 12, 76100 Rehovot, Israel
}

(Received 26 August 2016; revised 4 November 2016; accepted 4 November 2016; first published online 12 December 2016)

\section{SUMMARY}

Based on morphological and genetic characteristics, we describe a new species of Hepatozoon in the European wild cat (Felis silvestris silvestris), herein named Hepatozoon silvestris sp. nov. The study also provides the first data on the occurrence of $H$. felis in this wild felid. Hepatozoon meronts were observed in multiple cross-sections of different organs of four (44\%) cats. Additionally, extracellular forms, resembling mature gamonts of Hepatozoon, were found in the spleen and myocardium of two cats. Furthermore, tissues of six animals (67\%) were positive by PCR. Hepatozoon felis was identified infecting one cat $(11 \%)$, whereas the $18 \mathrm{~S}$ rRNA sequences of the remaining five cats $(56 \%)$ were identical, but distinct from the sequences of $\mathrm{H}$. felis. Phylogenetic analyses revealed that those sequences form a highly supported clade distant from other Hepatozoon spp. Future studies should include domestic cats from the areas where the wild cats positive for $H$. silvestris sp. nov. were found, in order to investigate their potential role to serve as intermediate hosts of this newly described species. Identification of its definitive host(s) and experimental transmission studies are required for elucidating the full life cycle of this parasite and the possible alternative routes of its transmission.

Key words: Hepatozoon silvestris sp. nov., Hepatozoon felis, European wild cat, Felis silvestris silvestris, morphology, molecular characterization, Bosnia and Herzegovina.

\section{INTRODUCTION}

Species of the genus Hepatozoon Miller (1908) are apicomplexan parasites that infect a wide range of vertebrate intermediate hosts (i.e. mammals, birds, reptiles, amphibians, marsupials), whereas haematophageous invertebrates (e.g. ticks, mosquitoes, mites, sand flies, fleas) may serve both as vectors and definitive hosts of these organisms (Smith, 1996). All species of Hepatozoon share a life cycle that involves sporogonic development and oocyst formation in the invertebrate host, and merogony and gametogony that occur in vertebrate hosts. Ingestion of the invertebrate host containing mature oocysts by the vertebrate host represents a main route of infection, although transplacental transmission and transmission by predation have also been reported (Murata et al. 1993; Johnson et al. 2009; Baneth et al. 2013). In addition to the meront stages, the occurrence of small tissue cysts

* Corresponding author: Department of Pathobiology, Institute of Parasitology, University of Veterinary Medicine Vienna, Veterinaerplatz 1, 1210 Vienna, Austria. E-mail: georg.duscher@vetmeduni.ac.at containing single or multiple parasitic stages (cystozoites) have been described in several species of Hepatozoon emphasizing the complexity of their life cycles (Smith, 1996). Tissue cysts are considered to be associated with parasite transmission by predation (Smith et al. 1994; Vincent-Johnson et al. 1997; Paperna et al. 2002; Baneth and Shkap, 2003; Baneth et al. 2007).

To date more than 340 species of Hepatozoon have been described with less than 50 of them in mammals, but a complete and documented life cycle is available only for few of them (Smith, 1996; Baneth, 1998). Several studies have also suggested that Hepatozoon may not be a single genus as it contains some distinct lineages (Kvičerová et al. 2014; Karadjian et al. 2015); however, division of the genus is considered controversial (Maia et al. 2016). The parasite in felids was first described in India and initially named Leucocytozoon felis domestici (Patton, 1908). Thereafter, it was transferred to the genus Hepatozoon due to the high morphological similarity of gamont stages found in the blood of cats to those of Hepatozoon canis, which mainly infects domestic and wild canids (Wenyon, 1926).

Parasitology (2017), 144, 650-661. C Cambridge University Press 2016. This is an Open Access article, distributed under the terms of the Creative Commons Attribution licence (http://creativecommons.org/licenses/by/4.0/), which permits unrestricted re-use, distribution, and reproduction in any medium, provided the original work is properly cited. 
Since then, Hepatozoon spp. have been reported in domestic cats and various species of wild cats, and it is assumed that two or more species could be found in felids worldwide (Criado-Fornelio et al. 2006; Kubo et al. 2010; Pawar et al. 2012; Baneth et al. 2013; Tateno et al. 2013). However, the parasite in cats was also referred to as Hepatozoon-like or Hepatozoon spp., without committing to a certain species, as the studies which described it were based only on morphological or genetic descriptions (Klopfer et al. 1973; Baneth et al. 1998; Perez et al. 2004; Rubini et al. 2006; Metzger et al. 2008; Ortuño et al. 2008; Salakij et al. 2008). Thereafter, the organism was finally morphologically and genetically characterized as Hepatozoon felis and recognized as the predominant agent of feline hepatozoonosis (Baneth et al. 2013).

The European wild cat (Felis silvestris silvestris) is the most common wild felid species in Europe, with populations living throughout the continent, and thus classified in the category of 'Least Concern' in the International Union for Conservation of Nature (IUCN) Red List of Threatened Species (Yamaguchi et al. 2015). In Bosnia and Herzegovina, wild cats inhabit the northeastern part of the country, and areas along the northern and eastern border where they live in sympatry with domestic cats (Yamaguchi et al. 2015). In the past few years, the interest of the scientific community in wild cats has increased as they have been recognized as natural reservoirs and potential source of pathogens for domestic cats (Falsone et al. 2014; Gallusová et al. 2016; Veronesi et al. $2016 a, b)$.

In the present study, we describe a new species of Hepatozoon in the European wild cat, based on morphological and genetic characteristics, herein designated as Hepatozoon silvestris sp. nov. Moreover, the study also provides the first data on the occurrence of $H$. felis in this wild felid.

\section{MATERIALS AND METHODS}

\section{Sample collection}

From 2011 to 2016, carcasses of nine adult European wild cats were collected in five municipalities of northwestern (Bihać, Bosanski Petrovac), northern (Odžak), eastern (Goražde) and central (Gornji Vakuf) Bosnia and Herzegovina (Table 1). All animals were killed by hunters and delivered for necropsy to the Department of Pathology of the Faculty of Veterinary Medicine in Sarajevo. At necropsy, carcasses were inspected for the presence of ticks, and origin, sex and age of each animal were recorded. Duplicate tissue samples (heart, lung, spleen, bone marrow, lingual muscle, diaphragm muscle, brachial muscle, masseter muscle) were collected, and either stored at $-20{ }^{\circ} \mathrm{C}$ until processed or fixed in $10 \%$

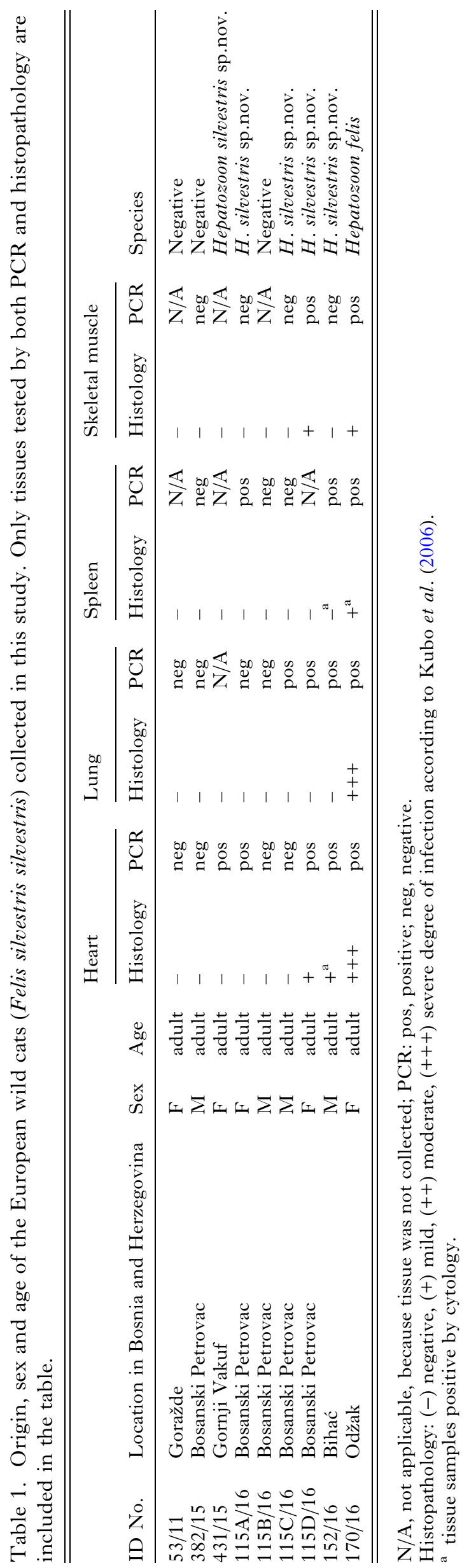


neutral-buffered formalin for up to $24 \mathrm{~h}$. However, not all the tissues were sampled from each wild cat. Ticks collected from the animals were stored in $70 \%$ ethanol and were sent along with frozen tissue samples to the Institute of Parasitology, University of Veterinary Medicine, Vienna, Austria for species identification (Estrada-Peña et al. 2004) and molecular analysis, respectively.

\section{Pathological and microscopic examination}

For histopathology, formalin-fixed tissue samples were routinely processed, embedded in paraffin and cut at 3-6 $\mu \mathrm{m}$ sections. Sections were deparaffinized and stained with haematoxylin and eosin (H\&E). In addition, multiple spleen and heart touch imprints from each animal were made on glass slides, stained with May-Grunwald-Giemsa and examined for the presence of parasitic forms. The degree of Hepatozoon parasitic load in tissue sections was graded according to Kubo et al. (2006) as negative $(-)$, mild $(+)$, moderate $(++)$ and severe $(+++)$. The presence of Hepatozoon oocysts in ticks collected was examined in haemolymph smears as previously described (Baneth et al. 2007). Developmental stages found in this study were measured with a calibrated ocular micrometre and sizes were expressed in micrometres $(\mu \mathrm{m})$ as mean \pm S.D. $(\times \pm$ S.D. $)$.

\section{DNA extraction, PCR amplification and sequencing}

Total DNA was extracted from 15 to $20 \mathrm{mg}$ of frozen heart, lung, spleen and brachial muscle tissue using the High Pure PCR Template Preparation Kit (Roche Diagnostics, Germany) and following the manufacturer's instructions. Paraffin-embedded tissues of three cats positive by histopathology (115A/16, 152/16, 170/16) were deparaffinized and subjected to DNA extraction using the same kit. However, from cat no. 170/16 there were only formalin-fixed samples.

A $620 \mathrm{bp}$ fragment of the $18 \mathrm{~S}$ rRNA gene of Hepatozoon spp. was amplified using the genusspecific primer set H14Hepa18SFw 5'-GAAAT AACAATACAAGGCAGT'TAAAATGCT-3' and H14Hepa18SRv 5'-GTGCTGAAGGAGTCG 'TTTATAAAGA-3' (Hodžić et al. 2015). Amplification was conducted under the following conditions: $95^{\circ} \mathrm{C}$ for $2 \mathrm{~min}$ followed by 35 cycles of $95^{\circ} \mathrm{C}$ for $1 \mathrm{~min}, 58^{\circ} \mathrm{C}$ for $1 \mathrm{~min}, 72^{\circ} \mathrm{C}$ for $1 \mathrm{~min}$. Final extension was performed at $72{ }^{\circ} \mathrm{C}$ for $5 \mathrm{~min}$. The PCR was carried out in a final volume of $25 \mu \mathrm{L}$ using $5 \times$ Green Reaction Buffer and GoTaq G2 ${ }^{\circledR}$ Polymerase (Promega, Germany). The DNA from tissue samples positive by PCR were additionally tested using primers HAM-1F 5'-GCCAG TAGTCATATGCTTGTC-3' and HPF-2R 5'-G ACTTC'TCCTTCGTCTAAG-3', which amplify approximately $1700 \mathrm{bp}$ long fragment of $18 \mathrm{~S}$ rRNA gene of Hepatozoon spp. (Criado-Fornelio et al. 2006), and obtained sequences were used for phylogenetic analyses. This PCR was processed under the following conditions: $95^{\circ} \mathrm{C}$ for $2 \mathrm{~min}$, then 35 cycles of $95^{\circ} \mathrm{C}$ for $30 \mathrm{~s}, 58^{\circ} \mathrm{C}$ for $30 \mathrm{~s}, 72^{\circ}$ $\mathrm{C}$ for $1.5 \mathrm{~min}$ and finally $72{ }^{\circ} \mathrm{C}$ for $5 \mathrm{~min}$. The second PCR assay was performed in a final volume of $25 \mu \mathrm{L}$ using Ilustra ${ }^{\mathrm{TM}}$ Hot Start Mix Ready-To-Go (GE Healthcare Europe $\mathrm{GmbH}$, Germany). DNA from a fox positive for H. canis was used as positive control in both PCRs.

To rule out possible misdiagnosis of Hepatozoon tissue forms with Toxoplasma gondii and Sarcocystis spp., DNA extracts from all tissue samples were tested for these pathogens using primers and PCR protocols published elsewhere (Homan et al. 2000; Kolenda et al. 2015).

PCR products were visualized by electrophoresis on 2\% agarose gel stained with Midori Green Advance DNA stain (Nippon Genetics Europe, Germany) and sequenced in both directions by a commercial company (LGC Genomics, Germany). Sequences obtained were edited with the BioEdit software v.7.2.5 (Hall, 1999) and compared for similarity with those available in GenBank ${ }^{\circledR}$ using Basic Local Alignment Search Tool (BLAST) analysis (http://www.ncbi.nlm.nih.gov/BLAST).

\section{Phylogenetic analyses}

For the construction of a phylogenetic tree, long $18 \mathrm{~S}$ rRNA nucleotide sequences obtained in the present study (1669 bp) were compared with the Hepatozoon spp. sequences deposited in the GenBank ${ }^{\circledR}$ database. Only the sequences with at least 945 bp overlapping were used for the overall alignment. The sequences were aligned by the MUSCLE algorithm (Edgar, 2004) and trimmed with trimAl v.1.2 tool (Capella-Gutiérrez et al. 2009). Sequence analyses were performed using the Maximum Likelihood (ML), Neighbor-Joining (NJ) and Maximum Pasrimony (MP) algorithms implemented with the bioinformatics software program MEGA v.7.0 (Kumar et al. 2016). A model test was used to determine the most suitable nucleotide substitution model and the T92 + G (Tamura 3-parameter) was the best fitting model according to AICc values (Akaike information criterion corrected). Phylogenetic trees were constructed with MEGA v.7.0 (Kumar et al. 2016) and tree topology (ML, MP) were completed using the Subtree Pruning and Regrafting heruistic model. Internal nodes of the tree were estimated with 1000 bootstrap replicates. Phylogenetic network was calculated with the short $18 \mathrm{~S}$ rRNA sequences herein generated (572 bp) and $H$. felis sequences from domestic and wild cats available in GenBank ${ }^{\circledR}$. The sequences of both datasets were aligned using MUSCLE 

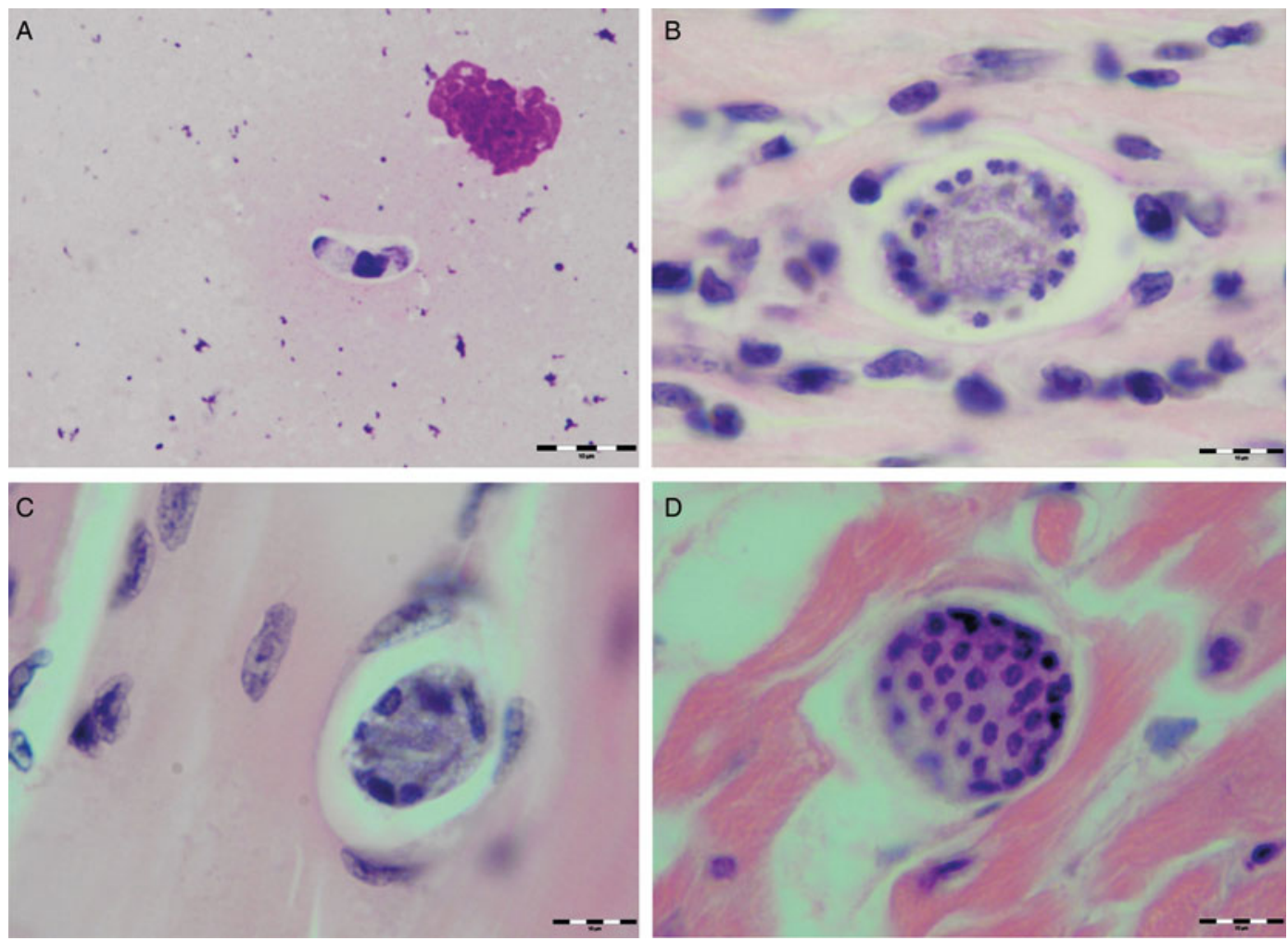

Fig. 1. Developmental stages of Hepatozoon silvestris sp. nov. in the myocardium and skeletal muscle of the European wild cat. (A) Extracellular gamont-like stage from the heart touch imprint. May-Grunwald-Giemsa stain. (B) Typical wheel spoke shaped meront with micromerozoites arranged in a circle around the basal material mass. Note the mild cellular infiltrate around the meront in the heart section. (C) Developing meront with elongated circularly aligned macromerozoites in the skeletal muscle. (D) Mature meront filled with numerous merozoites. H\&E stain (B-D).

(Edgar, 2004) and the phylogenetic network was calculated with Network software v.4.6.0.0 (fluxusengineering.com) applying the default settings. Unnecessary median vectors were reduced using MP option.

\section{Ethical statement}

All animals used in the present study were killed by licensed hunters in accordance with the Game law of Bosnia and Herzegovina ('OJ BiH', no. 4/06).

\section{RESULTS}

\section{Histopathological and microscopic findings}

Various developmental stages of Hepatozoon meronts were observed in multiple cross-sections in the myocardium, lungs, spleen and skeletal muscle tissue of four (44\%) out of nine European wild cats (Table 1, Figs 1, 2 and 3). These included early meronts with or without small nuclei surrounding a residual body (Figs. 2 and 3B), developing meronts containing micromerozoites circularly aligned along the meront wall (Figs 1B, 2 and 3C), meronts with larger peripherally arranged or dispersed macromerozoites (Fig. 1C), mature meronts with numerous merozoites irregularly scattered

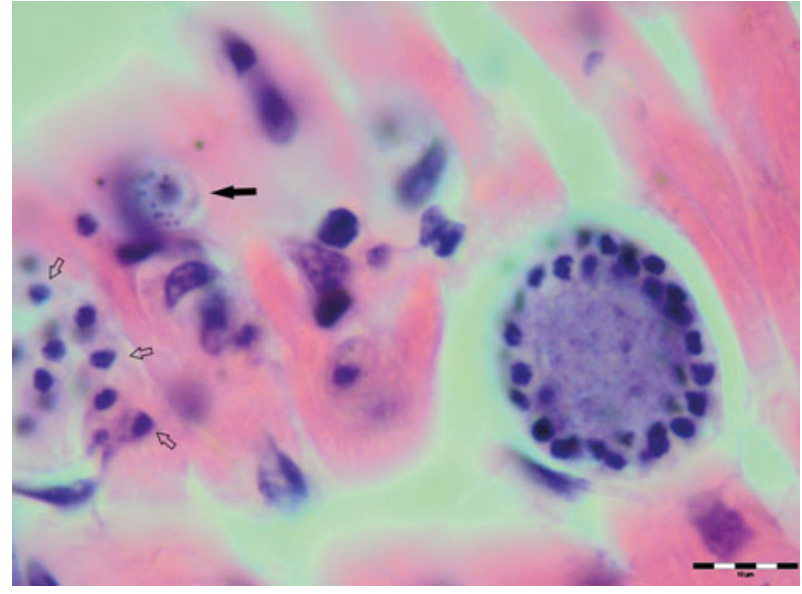

Fig. 2. Meronts of Hepatozoon silvestris sp. nov. in a myocarium section. An early meront with small nuclei surrounding a residual body (arrow), wheel spoke shaped meront with circularly arranged micromerozoites, and merozoites released from ruptured meront (open arrows). $\mathrm{H} \& \mathrm{E}$ stain

(Figs 1D and 3D), and ruptured meronts releasing merozoites (Fig. 2). Developing and mature meronts were the most common forms encountered, and the myocardium was the most frequently affected tissue among the tissues selected (Table 2). None of the structural Hepatozoon stages was 

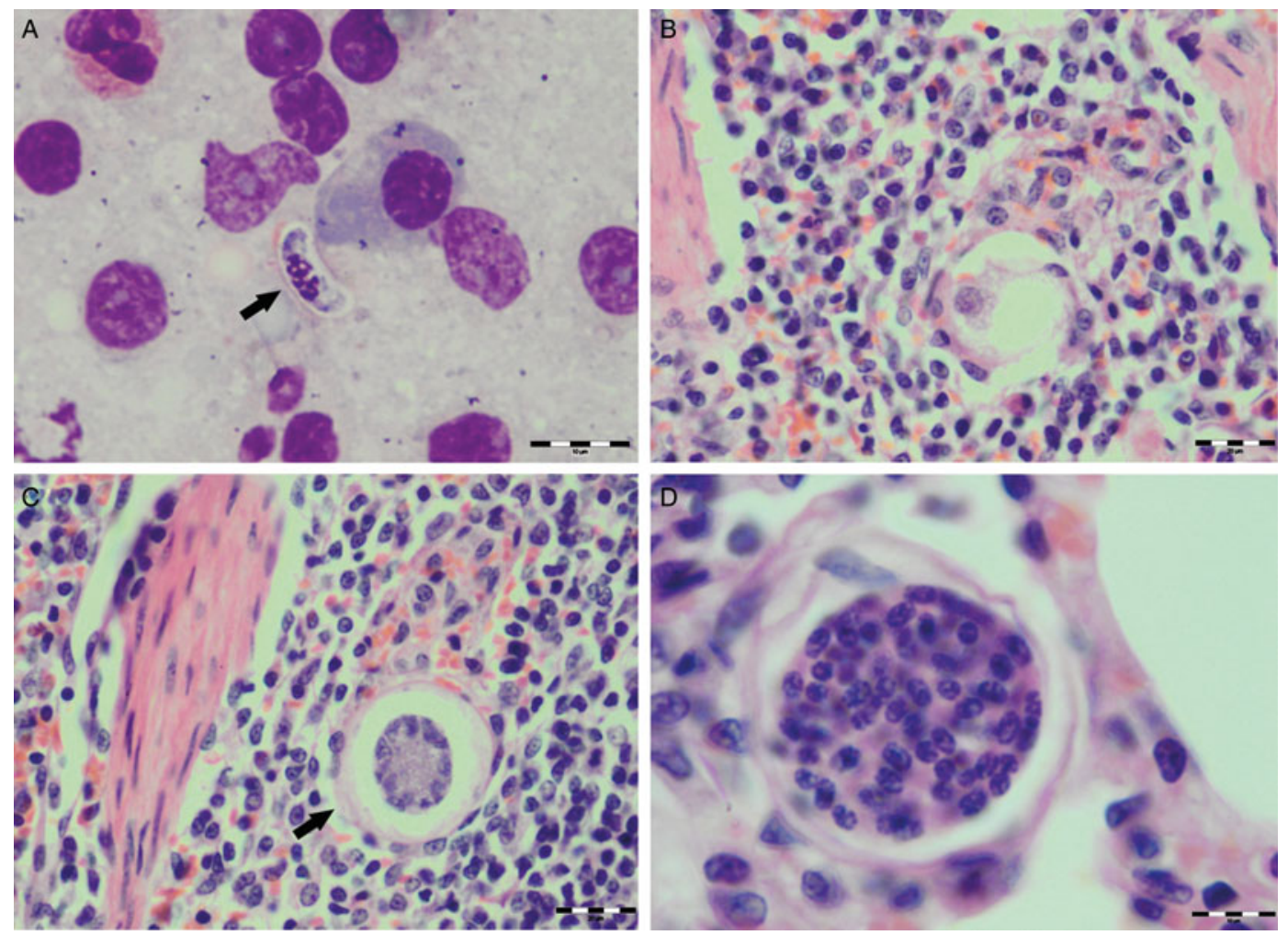

Fig. 3. Developmental stages of Hepatozoon felis in the spleen and lung of the European wild cat. (A) Extracellular gamont-like stage (arrow) from a spleen touch imprint. May-Grunwald-Giemsa stain. (B) An early meront in the spleen. (C) Wheel spoke shaped meront with triangular micromerozoites in the spleen. Note the width of external capsule (arrow).

(D) Mature meront in the lung section. H\&E stain (B-D).

found in the tongue, masseter, diaphragm or bone marrow. Three of the animals positive by histopathology were mildly parasitized (up to five meronts per slide), whereas numerous meronts were observed in the lungs ( $>50$ meronts per slide) and myocardium (>35 meronts per slide) of one cat (Table 2). Extracellular gamont-like forms were observed in May-Grunwald-Giemsa stained touch imprints of the spleen and myocardium of two cats (Figs 1A and $3 \mathrm{~A}$, Table 2). Substantial differences in appearance, shape and size of the forms found in the cats were apparent, suggesting the existence of two different parasite species. Briefly, size of the meront and gamont-like stages, width of the capsule surrounding the meronts, as well as arrangement, size and shape of merozoites within the wheel spokeshaped meronts were the most evident differences (Table 2, Figs 1-3).

Furthermore, multifocal infiltrates of mild to moderate numbers of lymphocytes, macrophages, and rare neutrophils and eosinophils were seen in the heart of three cats. Inflammatory cells were mostly located in the interstitium of subendocardial areas. Only a few intact meronts were surrounded with small numbers of inflammatory cells (Fig. 1B). In the skeletal muscle of two cats, a few areas of interstitium were infiltrated with small numbers of lymphocytes and macrophages. However, no inflammatory response was observed around the meronts.
In the severely affected cat (170/16), interalveolar and interlobular lung septa were distended and thickened with moderate numbers of inflammatory cells, mostly macrophages and lymphocytes. Multifocal areas of peribronchial and perivacular oedema were noticeable. Despite the presence of meronts confirmed by histopathology, no other lesions associated with Hepatozoon infection were found in the heart, spleen and muscle tissue of the cat. Moreover, four males and 17 semi- and fully engorged females of Ixodes ricinus were found on this cat, and no parasitic stages were observed in haemolymph smears of any of those ticks. This might be because the ticks did not feed on an infected animal in the nymphal stage or they were not examined after enough time to allow the development of the protozoan oocysts.

\section{Identification and molecular characterization of Hepatozoon spp.}

A total six $(67 \%)$ out of the nine wild cats collected were positive for Hepatozoon spp. by PCR using the genus-specific primers (H14Hepa18SFw and H14Hepa18SRv). The heart of five wild cats, lungs of four, spleen of three and brachial muscle of two cats scored positive (Table 2). For phylogenetic analyses, samples of all the six positive cats were additionally tested with another PCR protocol that amplifies a larger segment (approximately $1700 \mathrm{bp}$ ) 
Table 2. Measurements $(\mu \mathrm{m})$ of developmental stages of Hepatozoon silvestris sp. nov and Hepatozoon felis or closely relates species found in domestic and wild cats.

\begin{tabular}{|c|c|c|c|c|c|c|c|c|c|}
\hline $\begin{array}{l}\text { Hepatozoon } \\
\text { spp. }\end{array}$ & Intermediate host & Country & Gamont & Gamont nucleus & Meront & $\begin{array}{l}\text { Meront } \\
\text { capsule } \\
\text { (width) }\end{array}$ & Merozoite & Merozoite nucleus & Reference \\
\hline $\begin{array}{l}\text { H. silvestris } \\
\text { sp. nov. }\end{array}$ & $\begin{array}{l}\text { Felis silvestris } \\
\text { silvestris }\end{array}$ & $\begin{array}{l}\text { Bosnia and } \\
\text { Herzegovina }\end{array}$ & $11 \cdot 7 \pm 0.5 \times 5 \cdot 2 \pm 0 \cdot 7^{\mathrm{a}}$ & $6 \cdot 3 \pm 1 \cdot 3 \times 3 \cdot 0 \pm 0 \cdot 8^{\mathrm{a}}$ & $31 \cdot 7 \pm 4 \cdot 2 \times 22 \cdot 0 \pm 4 \cdot 6$ & $1 \cdot 1 \pm 0 \cdot 3$ & $\begin{array}{l}\text { Micromerozoite: } 4 \cdot 2 \pm \\
1 \cdot 1 \times 2 \cdot 5 \pm 0 \cdot 4 ; \\
\text { Macromerozoite: } 6 \cdot 0 \\
\pm 1 \cdot 0 \times 3 \cdot 2 \pm 0 \cdot 7\end{array}$ & $\begin{array}{l}\text { Micromerozoite: } 2 \cdot 6 \pm \\
0 \cdot 3 \text { Macromerozoite: } \\
4 \cdot 0 \pm 0 \cdot 3\end{array}$ & $\begin{array}{l}\text { Present } \\
\text { study }\end{array}$ \\
\hline H. felis & F.s. silvestris & $\begin{array}{l}\text { Bosnia and } \\
\text { Herzegovina }\end{array}$ & $10 \cdot 5 \pm 0 \cdot 4 \times 4 \cdot 4 \pm 0 \cdot 4^{\mathrm{a}}$ & $4 \cdot 7 \pm 0 \cdot 3 \times 4 \cdot 4 \pm 0 \cdot 3^{a}$ & $36 \cdot 4 \pm 5 \cdot 1 \times 31 \cdot 3 \pm 5 \cdot 1$ & $1 \cdot 4 \pm 0 \cdot 3$ & $7 \cdot 1 \pm 1 \cdot 0 \times 2 \cdot 5 \pm 0 \cdot 5$ & $2 \cdot 6 \pm 0 \cdot 2$ & $\begin{array}{l}\text { Present } \\
\text { study }\end{array}$ \\
\hline H. felis & Felis catus & Israel & $10 \cdot 5 \pm 0 \cdot 6 \times 4 \cdot 7 \pm 0 \cdot 8$ & $4 \cdot 0 \pm 0 \cdot 3 \times 3 \cdot 2 \pm 0 \cdot 5$ & $39 \cdot 0 \pm 5 \cdot 0 \times 34 \cdot 5 \pm 3 \cdot 8$ & $1 \cdot 4 \pm 0 \cdot 5$ & $7 \cdot 5 \pm 0 \cdot 6 \times 1 \cdot 9 \pm 0 \cdot 3$ & $2 \cdot 4 \pm 0.5 \times 1 \cdot 6 \pm 0.3$ & Baneth et al. \\
\hline H. felis & $\begin{array}{c}\text { Prionailurus } \\
\text { bengalensis }\end{array}$ & Korea & $\mathrm{N} / \mathrm{A}$ & $\mathrm{N} / \mathrm{A}$ & $31 \pm 4 \times 19 \pm 3$ & $\mathrm{~N} / \mathrm{A}$ & $\mathrm{N} / \mathrm{A}$ & N/A & $\begin{array}{l}\text { Kubo et al. } \\
(2010)\end{array}$ \\
\hline $\begin{array}{l}\text { Hepatozoon } \\
\text { spp. }\end{array}$ & P. bengalensis & Thailand & $9 \cdot 8 \pm 0 \cdot 4 \times 5 \cdot 2 \pm 0 \cdot 4$ & $\mathrm{~N} / \mathrm{A}$ & $\mathrm{N} / \mathrm{A}$ & $\mathrm{N} / \mathrm{A}$ & $\mathrm{N} / \mathrm{A}$ & $\mathrm{N} / \mathrm{A}$ & Salakij et al. \\
\hline $\begin{array}{l}\text { Hepatozoon } \\
\text { spp. }\end{array}$ & $\begin{array}{l}\text { Prionailurus } \\
\text { planiceps }\end{array}$ & Thailand & $9 \cdot 9 \pm 1 \cdot 1 \times 4 \cdot 8 \pm 0 \cdot 6$ & $\mathrm{~N} / \mathrm{A}$ & $\mathrm{N} / \mathrm{A}$ & N/A & $\mathrm{N} / \mathrm{A}$ & $\mathrm{N} / \mathrm{A}$ & $\begin{array}{l}\text { Salakij et al. } \\
(2008)\end{array}$ \\
\hline $\begin{array}{l}\text { Hepatozoon } \\
\text { spp. }\end{array}$ & Leopardus pardalis & Brazil & $7 \cdot 43 \times 4 \cdot 23$ & $\mathrm{~N} / \mathrm{A}$ & N/A & $\mathrm{N} / \mathrm{A}$ & $\mathrm{N} / \mathrm{A}$ & $\mathrm{N} / \mathrm{A}$ & $\begin{array}{l}\text { Metzger } \\
\text { et al. } \\
(2008)\end{array}$ \\
\hline $\begin{array}{l}\text { Hepatozoon } \\
\text { spp. }\end{array}$ & $\begin{array}{l}\text { Felis iriomotensis, } \\
\text { Felis bengalensis } \\
\text { euptilura }\end{array}$ & Japan & N/A & N/A & $22 \cdot 3 \pm 3 \cdot 1 \times 15 \cdot 3 \pm 2 \cdot 2$ & $\mathrm{~N} / \mathrm{A}$ & $6 \cdot 1 \pm 0 \cdot 6 \times 2 \cdot 3 \pm 0 \cdot 2$ & N/A & $\begin{array}{l}\text { Kubo et al. } \\
(2006)\end{array}$ \\
\hline $\begin{array}{l}\text { Hepatozoon } \\
\text { spp. }\end{array}$ & Panthera leo & Tanzania & $\mathrm{N} / \mathrm{A}$ & N/A & $30 \times 23$ & $\mathrm{~N} / \mathrm{A}$ & $\mathrm{N} / \mathrm{A}$ & N/A & $\begin{array}{l}\text { Averbeck } \\
\text { et al. } \\
\text { (1990) }\end{array}$ \\
\hline $\begin{array}{l}\text { Hepatozoon } \\
\text { spp. }\end{array}$ & Felis catus & Israel & N/A & N/A & $22 \pm 4 \cdot 8$ & $\mathrm{~N} / \mathrm{A}$ & N/A & N/A & $\begin{array}{l}\text { Klopfer } \\
\text { et al. } \\
\text { (1973) }\end{array}$ \\
\hline
\end{tabular}

N/A, data not available.

refers to gamont-like stage. 
of the 18S rRNA gene of Hepatozoon spp. This PCR produced positive results in frozen samples of five cats, but not in paraffin-embedded tissues of a cat positive in the first PCR. However, only three high-quality sequences were obtained and used for phylogenetic analyses. None of the samples tested were PCR positive for T. gondii or Sarcocystis spp.

Analysis and BLAST search of the short sequence (572 bp) obtained from one wild cat yielded 100\% identity to the sequences of $H$. felis previously described in Iriomote cat (Prionailurus iriomotensis), Tsushima leopard cat (Prionailurus bengalensis euptilurus) and their ticks from Japan (GenBank ${ }^{\circledR}$ accession numbers: AB771513, AB771568 and AB983435, respectively). Sequences of the remaining five PCR positive cats (five of the shorter and three of the longer fragment) were identical to each other, but distinct from the sequences of $H$. felis. The short sequences displayed a $96 \%$ identity to the most closely related sequences of $H$. felis haplotypes (JN584475, HQ829439, HQ829444, AY628681, AY620232, JN123435) detected in domestic and various species of wild cats. Regarding the longer sequences herein generated (1669 bp), they shared a 97\% identity with the $H$. felis (AY628681, AY620232) sequences from domestic cats (Felis catus), and $96 \%$ identity to H. canis (AY150067, $\mathrm{KC138531)}$ and Hepatozoon ayorgbor (EF157822) sequences previously found in the red fox (Vulpes vulpes), domestic cat (Felis catus) and the ball python (Python regius), respectively.

\section{Description}

Hepatozoon silvestris sp. nov.

(Figures 1-3).

Meront: Round to oval with a mean length of $31.7 \pm 4.2 \mu \mathrm{m} \quad(22 \cdot 1-38.7 \mu \mathrm{m}) \quad$ by $22.0 \pm 4.6 \mu \mathrm{m}$ $(11.9-28.3 \mu \mathrm{m})$ and a shape index (length/width ratio) of $1 \cdot 4(n=16)$. Meronts were enveloped by a relatively thick capsule (mean width $1 \cdot 1 \pm 0 \cdot 3 \mu \mathrm{m}$, $0.51-1.79 \mu \mathrm{m}, n=7$ ), which separated them from the surrounding tissues. Early meronts were smaller and comprised light basophilic to amphophilic amorphous material that sometimes contained small vacuoles and peripherally arranged nuclei. Two types of developing meronts were observed. Typical wheel spoke-shaped meronts contained approximately $20-30$ small, round to oval micromerozoites arranged in a circle around the basal material mass; and a second type of meronts contained 2-8 larger and elongate macromerozoites dispersed within the meront, and sometimes circularly arranged leaning with the longer side against the meront wall. Mature meronts were characterized by numerous merozoites irregularly scattered across the light basophilic amorphous material. Micromerozoites were $4.2 \pm 1.1 \mu \mathrm{m} \times 2.5 \pm 0.4 \mu \mathrm{m}$ (2.6-6.3 $\mu \mathrm{m} \times 1 \cdot 9-3.3 \mu \mathrm{m}, \quad n=23)$ with a shape index of $1 \cdot 7$, and macromerozoites measured $6 \cdot 0 \pm$
$1 \cdot 0 \mu \mathrm{m} \times 3 \cdot 2 \pm 0 \cdot 7 \mu \mathrm{m}(4 \cdot 3-7 \cdot 8 \mu \mathrm{m} \times 2 \cdot 5-4 \cdot 7 \mu \mathrm{m}, n=$ $9)$ with a shape index of $1 \cdot 9$. Round to oval dark condensed micromerozoite nuclei were $2 \cdot 6 \pm 0 \cdot 3 \mu \mathrm{m}$ $(2 \cdot 0-3 \cdot 5 \mu \mathrm{m}, \quad n=58)$, whereas macromerozoite nuclei were ellipsoid to rectangular and measured $4 \cdot 0 \pm 0 \cdot 3 \mu \mathrm{m}$ in length $(3 \cdot 5-4 \cdot 4 \mu \mathrm{m}, n=8)$.

Gamont-like stage: Elongated, slightly bended at the ends, and surrounded with a delicate capsule. The mean size was $11.7 \pm 0.5 \mu \mathrm{m} \times 5 \cdot 2 \pm$ $0.7 \mu \mathrm{m} \quad(11 \cdot 0-12.7 \mu \mathrm{m} \times 4 \cdot 1-6.6 \mu \mathrm{m}, n=11)$. The cytoplasm was light basophilic, sometimes with darker granules posterior and anterior to the centrally situated, purple to dark kidney-shaped and compact nucleus. The nucleus measured $6 \cdot 3 \pm$ $1.3 \mu \mathrm{m} \times 3.0 \pm 0.8 \mu \mathrm{m} \quad(4.1-7.8 \mu \mathrm{m} \times 2.0-4.7 \mu \mathrm{m}, n$ 11). Shape index of gamont-like stage and its nucleus was $2 \cdot 3$ and $2 \cdot 1$, respectively.

\section{Taxonomic summary}

Type-host: Felis silvestris silvestris Schreber, 1777

Other hosts: unknown

Vector: unknown

Site of infection: Meronts and gamont-like stages were observed in heart, spleen and skeletal muscle tissue by cytology and histopathology. Likewise, lungs and spleen were positive by PCR and sequencing

Type-locality: Bihać $(44 \cdot 8119628 \mathrm{~N}, 15 \cdot 8685645 \mathrm{E})-$ Bosnia and Herzegovina

Other localities: Bosanski Petrovac (44.550306N, 16.364375E), Gornji Vakuf (43.9375436N, 17.5880462E) - Bosnia and Herzegovina

Prevalence: Five out of nine (56\%) F. silvestris silvestris were positive

Type-material: Spleen and heart smears and histology slides from the type-host are deposited in the parasites collection of the Pathology Museum, Faculty of Veterinary Medicine, University of Sarajevo, Bosnia and Herzegovina (accession numbers: VFS-PAT-OP152/16-1, VFS-PATOP152/16-2, VFS-PAT-OP152/16-3)

Other material: DNA samples are kept at the Institute of Parasitology, University of Veterinary Medicine Vienna, Austria

Representative DNA sequences: Two sequences representing a 572 and $1669 \mathrm{bp}$ fragment of the 18S rRNA gene have been deposited in the GenBank $^{\circledR}$ database and are available under accession numbers KX757031 and KX757032, respectively

ZooBank registration: In accordance with section 8.5 of the International Code of Zoological Nomenclature (ICZN), details of the new species have been submitted to ZooBank with the Life Science Identifier (LSID) urn:lsid:zoobank.org: pub:FB2935A0-617E-4E55-8C32-543493A5FD61

Etymology: The species name follows the typehost species name, it is used as Latin adjective (silvestris $=$ from forest, sylvan) 
Remarks: Based on histopathological findings, spleen and heart cytology, morphological and morphometric characteristics of developmental stages and finally molecular and phylogenetic analyses, the parasite reported in this study represents a new species, herein described as $H$. silvestris sp. nov. The life stages observed in the stained spleen and heart touch imprints of two cats (Figs $1 \mathrm{~A}$ and $3 \mathrm{~A}$ ) resembled mature Hepatozoon gamonts based on their structure, shape, size and presence of the capsule. However, these forms were found only extracellularly, and not in blood cells, which are specific for gamonts. Consequently, it is difficult to explicitly state whether they represent gamonts released after blood cell membrane damage or even free zoites released from tissue cysts, which could be similar in appearance (Baneth and Shkap, 2003; Baneth et al. 2007). Therefore, we refer to these stages of both Hepatozoon spp. identified in this study as 'gamont-like stages'.

Of all Hepatozoon species described in carnivores, $H$. silvestris $\mathrm{sp}$. nov. is morphologically and genetically most similar to $H$. felis, but the following features can be used to distinguish the two species: (1) Meronts of $H$. silvestris $\mathrm{sp}$. nov. have thinner capsule; (2) Wheel spoke-shaped meronts of $H$. silvestris sp. nov. contain 20-30 micromerozoites, whereas H. felis meronts contain 10-15 micromerozoites; (3) Micromerozoites of $H$. silvestris sp. nov. are smaller and round to oval in shape; in $H$. felis, micromerozoites are larger, rectangular or triangular in shape and oriented perpendicularly to the meront wall.

\section{Phylogenetic analyses}

The overall topology of NJ, ML and MP trees inferred based on the total alignment of 28 sequences of Hepatozoon spp. (945 bp), including sequences of Adelina grylli (DQ096836) and Adelina dimidiata (DQ096835) as outgroups, showed the similar branching pattern and indicated the existence of three clades formed by Hepatozoon spp. from European and Asian felid hosts (Fig. 4). The sequences of $H$. silvestris sp. nov. found in European wild cats fall within the first clade $(100 \%$ bootstrap by all methods used), whereas the remaining two clades contain sequences of $H$. felis (or closely related species) from Indian wild cats and domestic cats from Israel and Spain. The MedianJoining network generated using the partial $18 \mathrm{~S}$ rRNA sequences obtained in this study along with 51 sequences of $H$. felis retrieved from the GenBank $^{\circledR}$ database displayed similar pattern with two well-separated clades (Fig. 5). The first clade contains sequences of $H$. felis representing 21 different haplotypes identified in domestic and wild cats (including a wild cat from this study), whereas the second clade exclusively contains sequences of H. silvestris sp. nov. from European wild cats (Fig. 5).
DISCUSSION

Our study reports the first detection of Hepatozoon spp. in European wild cats and clearly indicates the existence of two morphologically and genetically distinct species, namely $H$. felis and the newly characterized $H$. silvestris sp. nov. The phylogenetic tree herein generated shows that $H$. silvestris sp. nov. clusters with other Hepatozoon spp. from carnivores such as $H$. canis, $H$. americanum and $H$. felis, and would also fall within Clade A (Kvičerová et al. 2014) or the narrower Hepatozoon genus proposed by another study addressing the different lineages in the genus (Karadjian et al. 2015). Moreover, sequences of $H$. felis from domestic and wild cats used for phylogenetic analysis in this study, formed two highly supported clades indicating that probably only one of them could be referred to as $H$. felis, and another one may represent a different species as already suggested (Pawar et al. 2012).

Microscopically, two different life stages were observed from the infected animals by cytology and histopathology. Meronts were the most frequently encountered protozoan stage and different developing types were found to be present in heart, lungs, spleen and skeletal muscle tissue. Regarding the morphometric characteristics, meronts of $H$. silvestris sp. nov. observed in tissue sections differ in size, shape and merozoites arrangement compared with those of $H$. felis or closely related species reported from domestic and wild cats (Table 2). In general, meronts of $H$. silvestris sp. nov. (31.7 \pm $4 \cdot 2 \mu \mathrm{m} \times 22 \cdot 0 \pm 4 \cdot 6 \mu \mathrm{m})$ were smaller in size than the $H$. felis meronts $(36 \cdot 4 \pm 5 \cdot 1 \mu \mathrm{m} \times 31 \cdot 3 \pm 5 \cdot 1 \mu \mathrm{m})$ found in this study, and also to those described in domestic cats, which were $39 \cdot 0 \pm 5 \cdot 0 \mu \mathrm{m} \times 34.5 \pm$ $3.8 \mu \mathrm{m}$ (Baneth et al. 2013). However, the mean size of the $H$. silvestris sp. nov. meronts was larger in comparison to those of Hepatozoon spp. reported from the Iriomote cat, leopard cat $(P$. bengalensis $)$ and domestic cat which were $22 \cdot 3 \pm 3 \cdot 1 \mu \mathrm{m} \times 15 \cdot 3$ $\pm 2 \cdot 2 \mu \mathrm{m}$ (Kubo et al. 2006) and $22 \pm 4 \cdot 8 \mu \mathrm{m}$ in length (Klopfer et al. 1973), respectively, and similar in size to the meronts observed in the myocardium of the leopard cat $(31 \pm 4 \mu \mathrm{m} \times 19 \pm 3 \mu \mathrm{m}$, Kubo et al. 2010) and lion (Panthera leo $)(30 \times 23$ $\mu \mathrm{m}$ in length, Averbeck et al. 1990). The differences in the sizes of meronts between the studies may be due to different fixation procedures used for specimens preparation, errors in measurement or even affiliation to different species or strains of Hepatozoon as already suggested (Baneth and Shkap, 2003; Kubo et al. 2010). Histopathology revealed the presence of two types of developing meronts in wild cats infected with $H$. silvestris sp. nov. similar to those described in $H$. canis (Baneth et al. 2007). Meronts with a typical wheel spoke pattern containing 20-30 small round to oval micromerozoites, and a second type containing 2-8 larger 


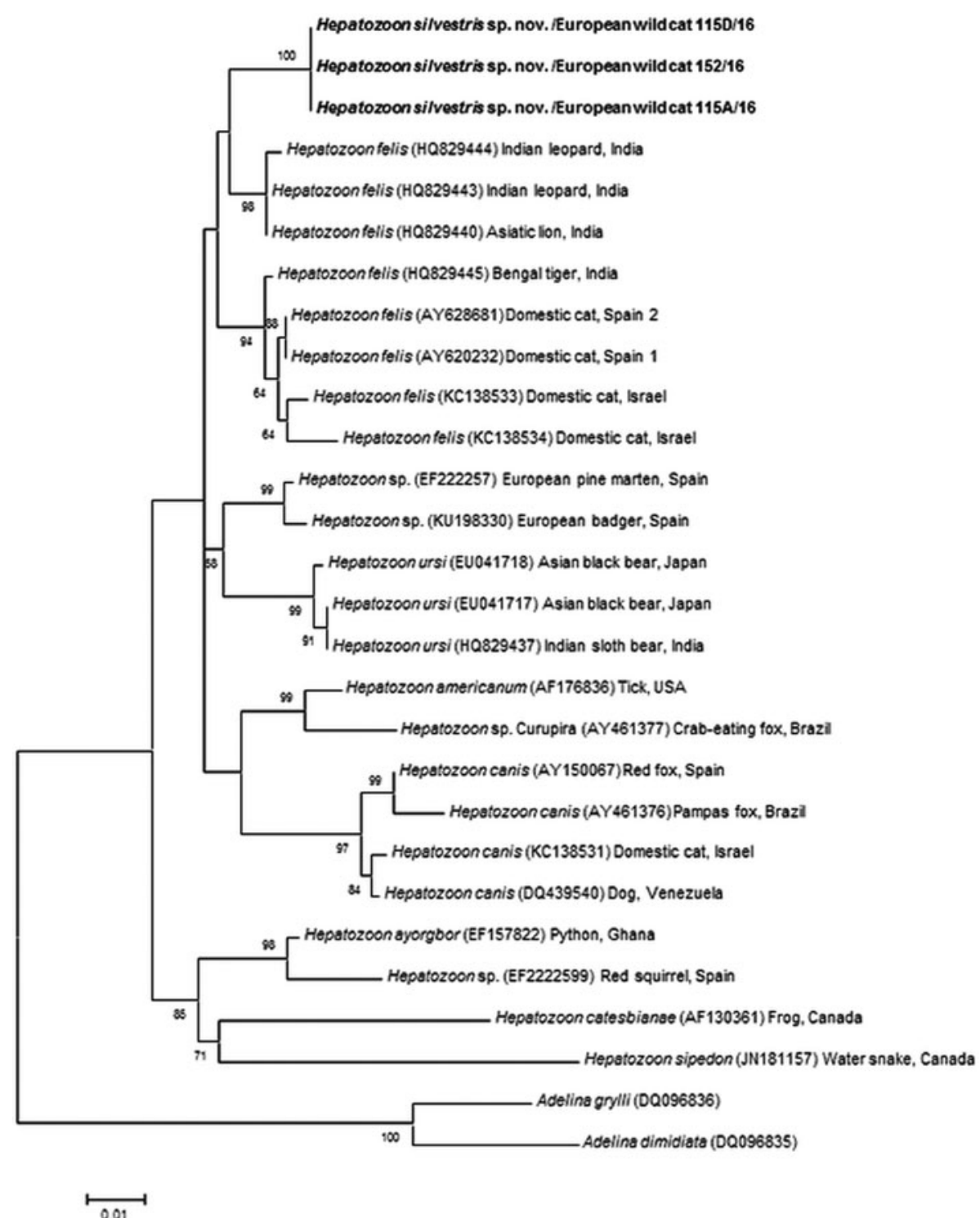

Fig. 4. Maximum Likelihood (ML) bootstrap tree with $18 \mathrm{~S}$ rRNA nucleotide sequences of Hepatozoon silvestris sp. nov. $(1669 \mathrm{bp})$ from this study compared to other Hepatozoon sequences deposited in GenBank ${ }^{\circledR}$ database. The tree with the highest log likelihood (-3128.227) is shown. Accession numbers (in brackets), host and origin for each sequence analysed are indicated. Bootstrap values based on 1000 replicates are indicated at the nodes (only values over $50 \%$ are included). The sequences generated in this study are presented in bold.

macromerozoites either dispersed within the meront or evenly lined up with longer side along the meront wall. However, only one meront type of $H$. felis with 10-15 circularly arranged large, rectangular or triangular micromerozoites oriented perpendicularly to the meront wall was observed in tissue sections of the heart, lungs and spleen (Fig. 3C). This type of meront has not been found in $H$. felis-infected domestic cats (Baneth et al. 2013), but similar structures have been described in the heart of wild cats in Japan (Kubo et al. 2006). Furthermore, the capsule that surrounds the meronts of $H$. silvestris sp. nov. was thinner $(1 \cdot 1 \pm 0 \cdot 3 \mu \mathrm{m})$ than the capsule of $H$. felis $(1 \cdot 4 \pm 0 \cdot 3 \mu \mathrm{m})$.

Meronts of $H$. silvestris sp. nov. were found in cardiac and skeletal muscle tissue, but the parasite's
DNA was also detected by PCR in the lungs and spleen of infected animals. Predilection to muscle tissue has also been reported in domestic and wild cats infected with H. felis (Klopfer et al. 1973; Averbeck et al. 1990; Beaufils et al. 1998; Kubo et al. 2006, 2010; Baneth et al. 2013) and dogs and wildlife infected with Hepatozoon americanum (Vincent-Johnson et al. 1997). This is substantially different from $H$. canis where infection is associated with the occurrence of meronts in haemolymphoid tissues (e.g. spleen, lymph nodes and bone marrow) and not in muscle tissue (VincentJohnson et al. 1997; Baneth et al. 2007, 2013). However, H. americanum produces 'onion skin' cysts in skeletal muscles, which are much larger and different in appearance than $H$. silvestris sp. 


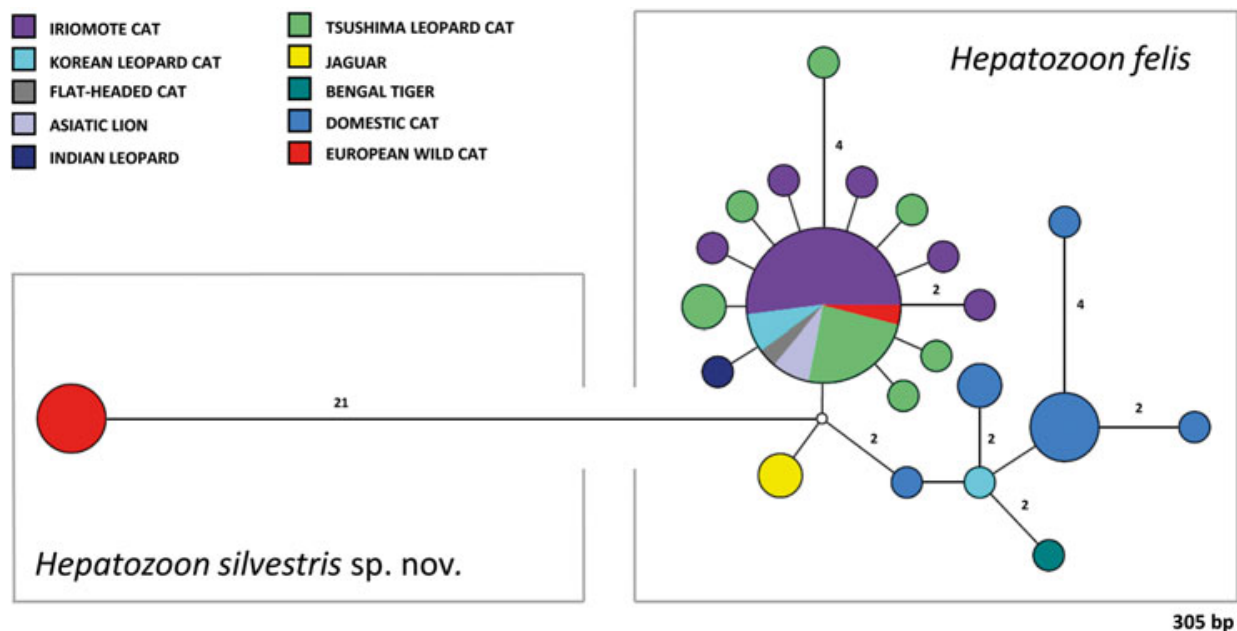

Fig. 5. Median-Joining network of the $18 \mathrm{~S}$ rRNA gene of Hepatozoon felis and newly described Hepatozoon silvestris sp. nov. (572 bp) constructed using the Network software. The size of the circles in the network is proportional to the number of sequences sharing the same haplotype. Numbers along branches indicate the number of substitutions between haplotypes.

nov. or H. felis meronts, and give rise to severe pyogranulomatous myositis, muscular hyperaesthesia and periostal reaction (Vincent-Johnson et al. 1997; Ewing and Panciera, 2003). Nevertheless, mild myocarditis with multifocal infiltrates of lymphocytes, macrophages, and rare neutrophils and eosinophils were observed in the heart of three cats infected with $H$. silvestris sp. nov., but not in the cat severely infected with meronts of $H$. felis. Similar lesions have been described in African and Asian wild cats, spotted hyenas (Crocuta crocuta) and Pampas grey fox (Lycalopex gymnocercus) infected with $H$. felis or closely related species (Kubo et al. 2006, 2010; East et al. 2008; Giannitti et al. 2012). Moreover, elevated activities of serum lactate dehydrogenase and creatine kinase have been reported in domestic cats with hepatozoonosis indicating muscular tissue damage (Baneth et al. 1998; Perez et al. 2004).

The gamont-like stage of $H$. silvestris sp. nov. is bigger in size $(11.7 \pm 0.5 \mu \mathrm{m} \times 5.2 \pm 0.7 \mu \mathrm{m})$ than that of $H$. felis $(10.5 \pm 0.4 \mu \mathrm{m} \times 4.4 \pm 0.4 \mu \mathrm{m})$ and it has a more compact nucleus that is longer and narrower $(6.3 \pm 1.3 \mu \mathrm{m} \times 3.0 \pm 0.8 \mu \mathrm{m})$ than the less densely appearing nucleus of $H$. felis $(4 \cdot 7 \pm 0 \cdot 3$ $\mu \mathrm{m} \times 4 \cdot 4 \pm 0 \cdot 3 \mu \mathrm{m})$. However, the gamont-like stage of $H$. felis is very similar in appearance and size to the gamonts of $H$. felis described in stained blood smears from domestic cats $(10 \cdot 5 \pm 0.6 \mu \mathrm{m} \times$ $4 \cdot 7 \pm 0 \cdot 8 \mu \mathrm{m}$, Baneth et al. 2013), and bigger than those of Hepatozoon spp. from the ocelot (Leopardus pardalis) $(7 \cdot 43 \times 4 \cdot 23 \mu \mathrm{m})$, flat-headed cat (Prionailurus planiceps) $(9 \cdot 9 \pm 1 \cdot 1 \mu \mathrm{m} \times 4 \cdot 8 \pm 0 \cdot 6$ $\left.\mu \mathrm{m}^{2}\right)$ and leopard cat $(9 \cdot 8 \pm 0 \cdot 4 \mu \mathrm{m} \times 5 \cdot 2 \pm 0 \cdot 4 \mu \mathrm{m})$ (Metzger et al. 2008; Salakij et al. 2008, 2010).

The vectors of feline hepatozoonosis are unknown, and in general data regarding the blood sucking invertebrates parasitizing wild cats in
Europe are scarce. A recent study on wild cats in Romania showed that $I$. ricinus was the dominant tick species infesting wild cats (Gallusová et al. 2016), which is in agreement with our study in which it was also the only species found. However, no evidence of infection with Hepatozoon oocysts was found in ticks collected from the European wild cat. Furthermore, other alternative routes of the parasite's transmission should be considered (Baneth et al. 2013). The detection of H. silvestris sp. nov. meronts in the cardiac and skeletal muscle tissues of the infected animals and, molecularly, in lungs and spleen, along with the marked predatory behaviour of wild felids, might suggest that the infection is transmitted by carnivorism. This could be also supported by the lack of detection of gamonts in circulating leucocytes, such as neutrophils and monocytes.

\section{Concluding remarks}

In this study, we described a new species of Hepatozoon, clearly distinct from $H$. felis, found to infect European wild cats in Bosnia and Herzegovina. In addition, the study reports the occurrence of $H$. felis for the first time in wild cats in Europe, extending the host and distribution range of this feline parasite. The European wild cats and domestic cats are two close relatives, which may live in sympatry, interbreed and even produce fertile offspring (Mattucci et al. 2013). As a consequence of the close association between wild and domestic cats, both species may share pathogens and be at risk of the same infections (Veronesi et al. 2016b). Thus, future studies should also include domestic cats from the areas where the wild cats positive for $H$. silvestris sp. nov. were found, in order to investigate their potential ability to serve 
as intermediate hosts of this newly described species. Furthermore, identification of its definitive host(s) and experimental transmission studies are required for elucidating the life cycle and possible alternative routes of transmission.

\section{ACKNOWLEDGEMENTS}

The authors would like to thank Edo Softić, DVM (Veterinary Clinic, Bosanski Petrovac) for providing the animals and Alma Jahić (Department of Pathology, Faculty of Veterinary Medicine, University of Sarajevo) for her technical support. This study was conducted under the frame of EurNegVec COST Action TD1303.

\section{FINANCIAL SUPPORT}

This research received no specific grant from any funding agency, commercial or not-for-profit sectors.

\section{REFERENCES}

Averbeck, G. A., Bjork, K. E., Packer, C. and Herbst, L. (1990) Prevalence of hematozoans in lions (Panthera leo) and cheetah (Acinonyx jubatus) in Serengeti National Park and Ngorongoro Crater, Tanzania. Yournal of Wildlife Diseases 26, 392-394.

Baneth, G. (1998). Perspectives on canine and feline hepatozoonosis. Veterinary Parasitology 181, 3-11.

Baneth, G. and Shkap, V. (2003). Monozoic cysts of Hepatozoon canis. Fournal of Parasitology 89, 379-381.

Baneth, G., Aroch, I., Tal, N. and Harrus, S. (1998). Hepatozoon species infection in domestic cats: a retrospective study. Veterinary Parasitology 79, 123-133.

Baneth, G., Samish, M. and Shkap, V. (2007). Life cycle of Hepatozoon canis (Apicomplexa: Adeleorina: hepatozoidae) in the tick Rhipicephalus sanguineus and domestic dog (Canis familiaris). Fournal of Parasitology 93, 283-299.

Baneth, G., Sheiner, A., Eyal, O., Hahn, S., Beaufils, J. P., Anug, Y. and Talmi-Frank, D. (2013). Redescription of Hepatozoon felis (Apicomplexa: Hepatozoidae) based on phylogenetic analysis, tissue and blood form morphology, and possible transplacental transmission. Parasites and Vectors 6, 102.

Beaufils, J. P., Martin-Granel, J. and Jumelle, P. (1998). Hepatozoon spp. parasitemia and feline leukemia virus infection in two cats. Feline Practice 26, 10-13.

Capella-Gutiérrez, S., Silla-Martínez, J. M. and Gabaldón, T. (2009). trimAl: a tool for automated alignment trimming in large-scale phylogenetic analyses. Bioinformatics 25, 1972-1973.

Criado-Fornelio, A., Ruas, J. L., Casado, N., Farias, N. A. Soares, M. P., Müller, G., Brumt, J.G., Berne, M.E., BulingSaraña, A. and Barba-Carretero, J. C. (2006). New molecular data on mammalian Hepatozoon species (Apicomplexa: Adeleorina) from Brazil and Spain. Fournal of Parasitology 92, 93-99.

East, M. L., Wibbelt, G., Lieckfeldt, D., Ludwig, A., Goller, K., Wilhelm, K., Schares, G., Thierer, D. and Hofer, H. (2008). A Hepatozoon species genetically distinct from $H$. canis infecting spotted hyenas in the Serengeti ecosystem, Tanzania. Yournal of Wildlife Diseases 44, 45-52.

Edgar, R. C. (2004). MUSCLE: multiple sequence alignment with high accuracy and high throughput. Nucleic Acids Research 32, 4673-4680.

Estrada-Peña, A., Bouattour, A., Camicas, J. L. and Walker, A.R. (2004). Ticks of Domestic Animals in the Mediterranean Region: a Guide to Identification of Species. University of Zaragoza, Spain.

Ewing, S. A. and Panciera, R. J. (2003). American canine hepatozoonosis. Clinical Microbiology Review 16, 688-697.

Falsone, L., Brianti, E., Gaglio, G., Napoli, E., Anile, S., Mallia, E., Giannelli, A., Poglayen, G., Giannetto, S. and Otranto, D. (2014). The European wildcats (Felis silvestris silvestris) as reservoir hosts of Troglostrongylus brevior (Strongylida: Crenosomatidae) lungworms. Veterinary Parasitology 205, 193-198.

Gallusová, M., Jirsová, D., Mihalca, A.D., Gherman, C. M., D'Amico, G., Qablan, M. A. and Modrý, D. (2016). Cytauxzoon infections in wild felids from Carpathian-Danubian-Pontic space: further evidence for a different Cytauxzoon species in European felids. Fournal of Parasitology 102, 377-380.

Giannitti, F., Diab, S. S., Uzal, F. A., Fresneda, K., Rossi, D., TalmiFrank, D. and Baneth, G. (2012). Infection with a Hepatozoon sp. closely related to Hepatozoon felis in a wild Pampas gray fox (LycalopexPseudalopex-gymnocercus) co-infected with canine distemper virus. Veterinary Parasitology 186, 497-502.

Hall, T. A. (1999). BioEdit: a user-friendly biological sequence alignment editor and analysis program for Windows 95/98/NT. Nucleic Acids Symposium Series 41, 95-98.

Hodžić, A., Alić, A., Fuehrer, H. P., Harl, J., Wille-Piazzai, W. and Duscher, G. G. (2015). A molecular survey of vector-borne pathogens in red foxes (Vulpes vulpes) from Bosnia and Herzegovina. Parasites and Vectors $\mathbf{8}, 88$.

Homan, W. L., Vercammen, M., De Braekeleer, J. and Verschueren, H. (2000). Identification of a 200- to 300 -fold repetitive 529 bp DNA fragment in Toxoplasma gondii, and its use for diagnostic and quantitative PCR. International Fournal of Parasitology 30, 69-75. Johnson, E. M., Panciera, R. J., Allen, K. E., Sheets, M. E., Beal, J. D., Ewing, S. A. and Little, S. E. (2009). Alternate pathway of infection with Hepatozoon americanum and the epidemiologic importance of predation. Fournal of Veterinary Internal Medicine 23, 1315-1318.

Karadjian, G., Chavatte, J. M. and Landau, I. (2015). Systematic revision of the adeleid haemogregarines, with creation of Bartazoon n. g., reassignment of Hepatozoon argantis Garnham, 1954 to Hemolivia, and molecular data on Hemolivia stellata. Parasite 22, 31.

Klopfer, U., Nobel, T. A. and Neuman, F. (1973). Hepatozoon-like parasite (schizonts) in the myocardium of the domestic cat. Veterinary Pathology 10, 185-190.

Kolenda, R., Schierack, P., Zieba, F., Zwijacz-Kozica, T. and Bednarski, M. (2015). First molecular characterization of Sarcocystis tenella in Tatra chamois (Rupicapra rupicapra tatrica) in Poland. Parasitology Research 114, 3885-92.

Kubo, M., Miyoshi, N. and Yasuda, N. (2006). Hepatozoonosis in two species of Japanese wild cat. Fournal of Veterinary Medical Science 68, 833-837.

Kubo, M., Jeong, A., Kim, S. I., Kim, Y.J., Lee, H., Kimura, J., Agatsuma, T., Sakai, H. and Yanai, T. (2010). The first report of Hepatozoon species infection in leopard cats (Prionailurus bengalensis) in Korea. Fournal of Parasitology 96, 437-439.

Kumar, S., Stechter, G. and Tamura, K. (2016). MEGA7: Molecular Evolutionary Genetics Analysis version 7.0 for bigger datasets. Molecular Biology and Evolution 33, 1870-1874.

Kvičerová, J., Hypša, V., Dvořáková, N., Mikulíček, P., Jandzik, D., Gardner, M. G., Javanbakht, H., Tiar, G. and Siroký, P. (2014). Hemolivia and Hepatozoon: haemogregarines with tangled evolutionary relationships. Protist 165, 688-700.

Maia, J. O., Carranza, S. and Harris, D. J. (2016). Comments on the systemic revision of adeleid haemogregarines: is more data needed? Fournal of Parasitology 102, 549-552.

Mattucci, F., Oliveira, R., Bizzarri, L., Vercillo, F., Anile, S., Ragni, B., Lapini, L., Sforzi, A., Alves, P.C., Lyons, L. A. and Randi, E. (2013). Genetic structure of wildcat (Felis silvestris) populations in Italy. Ecology and Evolution 3, 2443-2458.

Metzger, B., Dos Santos Paduan, K., Rubini, A. S., De Oliveira, T. G., Pereira, C. and O'Dwyer, L. H. (2008). The first report of Hepatozoon sp. (Apicomplexa: Hepatozoidae) in neotropical felids from Brazil. Veterinary Parasitology 152, 28-33.

Murata, T., Inoue, M., Tateyama, S., Taura, Y. and Nakama, S. (1993). Vertical transmission of Hepatozoon canis in dogs. The Fournal of Veterinary Medical Science 55, 867-868.

Ortuño, A., Castellà, J., Criado-Fornelio, A., Buling, A. and BarbaCarretero, J. C. (2008). Molecular detection of a Hepatozoon species in stray cats from a feline colony in North-eastern Spain. Veterinary Fournal 177, 134-135.

Paperna, I., Kremer-Mecabell, T. and Finkelman, S. (2002) Hepatozoon kisrae n. sp. infecting the lizard Agama stellio is transmitted by the tick Hyalomma cf. aegyptium. Parasite $9,17-27$.

Patton, W.S. (1908). The haemogregarines of mammals and reptiles. Parasitology 1, 318-321.

Pawar, R. M., Poornachandar, A., Srinivas, P., Rao, K. R., Lakshmikantan, U. and Shivaji, S. (2012). Molecular characterization of Hepatozoon spp. infection in endangered Indian wild felids and canids. Veterinary Parasitology 186, 475-479.

Perez, R. R., Rubini, A. S. and O'Dwyer, L. H. (2004). The first report of Hepatozoon spp. (Apicomplexa, Hepatozoidae) in domestic cats from São Paulo state, Brazil. Parasitology Research 94, 83-85. 
Rubini, A. S., Dos Santos Paduan, K., Perez, R. R., Ribolla, P. E. and O'Dwyer, L. H. (2006). Molecular characterization of feline Hepatozoon species from Brazil. Veterinary Parasitology 137, 168-171.

Salakij, C., Salakij, J., Narkkong, N. A., Sirinarumitr, T. and Pattanarangsan, R. (2008). Hematologic, cytochemical, ultrastructural, and molecular findings of Hepatozoon-infected flat-headed cats (Prionailurus planiceps). Veterinary Clinical Pathology 37, 31-41.

Salakij, C., Sirinarumitr, T. and Tongthainun, D. (2010). Molecular characterization of Hepatozoon species in a leopard cat (Prionailurus bengalensis) from Thailand. Veterinary Clinical Pathology 39, 199-202.

Smith, T. G. (1996). The genus Hepatozoon (Apicomplexa: Adeleina). Fournal of Parasitology 82, 565-585.

Smith, T. G., Desser, S. S. and Martin, D. S. (1994). The development of Hepatozoon sipedon $\mathrm{n}$. sp. (Apicomplexa: Adeleina: Hepatozooidae) in its natural host, the northern water snake (Nerodia sipedon sipedon), the culicine vectors, Culex pipiens and Culex territans, and an intermediate host, the northern leopard frog (Rana pipiens). Parasitology Research 80, 559-568.

Tateno, M., Nishio, T., Matsuo, T., Sakuma, M., Nakanishi, N., Izawa, M., Asari, Y., Okamura, M., Shimokawa Miyama, T., Setoguchi, A. and Endo, Y. (2013). Epidemiological survey of tick- borne protozoal infection in Iriomote cats and Tsushima leopard cats in Japan. Fournal of Veterinary Medical Science 75, 985-989.

Veronesi, F., Ravagnan, S., Cerquetella, M., Carli, E., Olivieri, E., Santoro, A., Pesaro, S., Berardi, S., Rossi, G., Ragni, B., Beraldo, P. and Capelli, G. (2016a). First detection of Cytauxzoon spp. infection in European wildcats (Felis silvestris silvestris) of Italy. Ticks and Tick Borne Diseases 7, 853-858.

Veronesi, F., Traversa, D., Lepri, E., Morganti, G., Vercillo, F., Grelli, D., Cassini, R., Marangi, M., Iorio, R., Ragni, B. and Di Cesare, A. (2016b). Occurrence of lungworms in European wildcats (Felis silvestris silvestris) of Central Italy. Fournal of Wildlife Diseases 52, 270-278. Vincent-Johnson, N. A., Macintire, D. K., Lindsay, D. S., Lenz, S. D., Baneth, G., Shkap, V. and Blagburn, B. L. (1997). A new Hepatozoon species from dogs: description of the causative agent of canine hepatozoonosis in North America. Fournal of Parasitology 83, 1165-1172.

Wenyon, C. M. (1926). Protozoology: A manual for Medical Men, Veterinarians and Zoologists. William Wood, New York, pp. 1085-1095. Yamaguchi, N., Kitchener, A., Driscoll, C. and Nussberger, B. (2015). Felis silvestris. The IUCN Red List of Threatened Species 2015. http://dx.doi.org/10.2305/IUCN.UK.2015-2.RLTS.T60354712A50652361.en. Downloaded on August 4th 2016 